\title{
Chemical constituents from Swartzia apetala Raddi var. glabra and evaluation of their antifungal activity against Candida spp.
}

\author{
Marcelo Francisco de Araujo, *,1 Ivo José Curcino Vieira, ${ }^{1}$ Raimundo Braz-Filho, ${ }^{1}$ \\ Olney Vieira-da-Motta, ${ }^{2}$ Leda Mathias ${ }^{1}$
}

\author{
${ }^{1}$ Setor de Química de Produtos Naturais, Universidade Estadual do Norte Fluminense, Av. Alberto Lamego, 2000, \\ 28013-602 Campos dos Goytacazes-RJ, Brazil, \\ ${ }^{2}$ Laboratório de Sanidade Animal, Universidade Estadual do Norte Fluminense, Av. Alberto Lamego, 2000, \\ 28013-602 Campos dos Goytacazes-RJ, Brazil
}

\begin{abstract}
RESUMO: "Constituintes químicos de Swartzia apetala Raddi var. glabra e avaliação da atividade antifúngica contra espécies de Candida". Do extrato hexânico da madeira de Swartzia apetala Raddi var. glabra foram isolados um estilbeno (1), uma flavanona (2), um pterocarpano (3), um triterpeno (4) e uma mistura de esteróides (5 a 7). O extrato bruto e as substâncias isoladas foram submetidas à avaliação do potencial antifúngico usando nove cepas padrão ATCC do gênero Candida. Entre as substâncias testadas apenas o triterpeno (4) e a mistura de esteróides (5 a 7) não apresentaram atividade. As estruturas das substâncias foram determinadas através da análise dos espectros de CG/EM, e RMN (1D e 2D) e comparação com dados da literatura.
\end{abstract}

Unitermos: Swartzia apetala, atividade antifúngica, estilbeno, flavonoides, terpenóides.

\begin{abstract}
From the hexanic extract of the stem from Swartzia apetala Raddi var. glabra were isolated one stilbene (1), one flavanone (2), one pterocarpan (3), one triterpene (4) and a mixture of three steroids ( 5 to 7 ). The crude extract and the compounds isolated were submitted to evaluation of the antifungal activity against nine yeast standard ATCC of the Candida genus. Among the compounds only the triterpene (4) and the mixture of steroids (5 to 7) showed no activity. The structures of the compounds were determined by spectral data analysis of GC/MS and ${ }^{1} \mathrm{H}$ and ${ }^{13} \mathrm{C}$ NMR (1D and 2D experiments), as well as comparison with literature values.
\end{abstract}

Keywords: Swartzia apetala, antifungal activity, stilbene, flavonoids, terpenoids.

\section{INTRODUCTION}

The Swartzia genus (Fabaceae-Papilonoideae) comprehend about 130-140 species and only nine were chemically studied (Formiga et al., 1974; Braz-Filho et al., 1980; Sanchez et al., 1999; Magalhães et al., 2003; Rojas et al., 2006).

Swartzia apetala Raddi var. glabra is popularly known in Brazil as "arruda rajada" and has been used in civil construction and hydraulic workmanships on the basis of this large durability and impenetrability to marine worm (Rizzini and Mors, 1995), but yet without report of phytochemical investigation and evaluation of biological activity.

The yeast Candida is a widespread opportunistic pathogen. Mucocutaneous infections, that manifest as both oral and vaginal 'thrush' are commonly encountered and the incidence of systemic candidiasis has risen dramatically over the past decades in parallel with the increasing sophistication of medicinal technology and widespread use of aggressive therapeutic regimens for transplantation and cancer patients. With this is necessary and urgent the identification of novel bioactive compounds. Candida species are among the main fungi causing nosocomial infections (Rangel-Fausto et al., 1999; Aguiar et al., 2008), and other clinical human diseases special attention to HIV positive patients (Jadhav and Mishra, 2003).

This paper reports the first phytochemical study and evaluation of the biological activity from $S$. apetala Raddi var. glabra, allowing the isolation and characterization of the compounds (E)-3-hydroxy5-methoxystilbene (3-methoxy-5-styrylphenol, 1), (-)-5,7-dihydroxyflavanone (pinocembrin, 2), (-)-3-hydroxy-8,9-methylenedioxypterocarpan

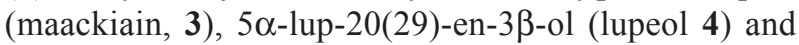
a mixture of (24-methylcholesta-5,22(E)-dien-3 $\beta$-ol, campesterol, 5), stigmast-5-en-3 $\beta$-ol (24-ethylcholest5-en-3 $\beta$-ol, $\beta$-sitosterol, 6) and 24-ethylcholesta-

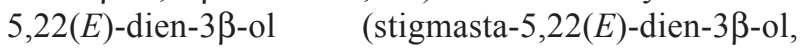
stigmasterol, 7) by spectral data (GC/MS, $1 \mathrm{D}$ and 2D NMR) and comparison with literature values, together 
with evaluation of the antifungal activity against nine yeast standard ATCC of the Candida genus.

\section{EXPERIMENTAL}

\section{General procedures}

Melting points are uncorrected. The ${ }^{1} \mathrm{H}$ and ${ }^{13} \mathrm{C}$ NMR spectra were recorded on a JEOL Eclipse spectrometer at 400 and $100 \mathrm{MHz}$ respectively, in $\mathrm{CDCl}_{3}$ with tetramethylsilane (TMS) as internal standard. Mass spectra were obtained with CGMS-QP 5050 SHIMADZU (EI, $70 \mathrm{eV}$ ). Optical rotation was measured with Perkin-Elmer 343 polarimeter at the sodium-D line.

\section{Plant material}

Swartzia apetala Raddi var. glabra was collected in Forest Reserve Vale do Rio Doce (CVRD) in November 1996, Espírito Santo, Brazil. The specimen was authenticated by the botanical identifier Domingos A. Folly by comparison with voucher of the herbarium company ( $\left.n^{\circ} 395\right)$.

\section{Extraction and isolation}

The dried stem of $S$. apetala $(0.58 \mathrm{~kg})$ was powdered and successively extracted by maceration at room temperature with hexane, $\mathrm{CH}_{2} \mathrm{Cl}_{2}$ and methanol. The hexane extract $(2.3 \mathrm{~g})$ was submitted to partition with EtOAc to obtain two fractions F1 and F2. The fraction soluble in EtOAc F1 was chromatographed on a silica gel column using a hexane- $\mathrm{CH}_{2} \mathrm{Cl}_{2}$-methanol gradient obtaining 38 fractions of $50 \mathrm{~mL}$ that were reunited of according to chromatographic profile resulting in four fractions (F1A, F1B, F1C and F1D). The fraction F1B $(110 \mathrm{mg}$ ) was purified by column chromatography on silica gel using a hexane- $\mathrm{CH}_{2} \mathrm{Cl}_{2}$-EtOAc-methanol gradient to obtain compounds 3-methoxy-5-styrylphenol $(1,7.0 \mathrm{mg})$ and pinocembrin $\{2,18.0 \mathrm{mg}$; m.p. 196$\left.198^{\circ} \mathrm{C} ;[\alpha]_{\mathrm{D}}-57^{\circ}\left(\mathrm{c} 0.003, \mathrm{CHCl}_{3}\right)\right\}$. The fraction F1C $(355 \mathrm{mg})$ was subjected to the same procedure used to F1B, obtaining 25 fractions of $50 \mathrm{~mL}$ and the fractions were reunited in three fractions (F1C-1 to F1C-3). The fraction $\mathrm{F} 1 \mathrm{C}-1(21 \mathrm{mg})$ was purified by preparative TLC using hexane- $\mathrm{CH}_{2} \mathrm{Cl}_{2}(3: 2)$ as eluent afforded the pterocapan maackiain $\left\{\mathbf{3}, 13.0 \mathrm{mg}\right.$; m.p. $180-185{ }^{\circ} \mathrm{C}$; $\left.[\alpha]_{\mathrm{D}}-268^{\circ}\left(\mathrm{c} 0.02, \mathrm{CHCl}_{3}\right)\right\}$. Fraction F1C-3 $(33.5 \mathrm{mg})$ was also subjected to preparative TLC using hexaneEtOAc (4:1) as eluent and afforded triterpenoid lupeol (4, 13 mg; m.p. $\left.213-215^{\circ} \mathrm{C}\right)$. Fraction F1D (230 mg) was chromatographed on silica gel column flash using petroleum ether-EtOAc $(8: 2)$ and obtained a mixture (35 $\mathrm{mg}$ ).of the steroids campesterol (5), $\beta$-sitosterol (6) and stigmasterol (7).

\section{Bioassay}

The evaluation of the potential antifungal of the extract and the isolated compounds was evaluated by the agar diffusion method (Hadaceck \& Greger, 2000). The yeasts inocula $(100 \mu \mathrm{L})$ were spread on the surface of Sabouraud dextrose agar (Difco, USA) in $100 \mathrm{~mm}$ x $17 \mathrm{~mm}$ plates Petri dishes by using a swab (Venturi, Transystem, Copan Innovation, Italy). The colonies<smiles>COc1cc(O)cc(C=Cc2ccccc2)c1</smiles>

1<smiles>C=C(C)[C@H]1CCC2(C)CC[C@]3(C)C(CCC4[C@@]5(C)CCC(O)C(C)(C)C5CC[C@]43C)C12</smiles><smiles>O=C1C[C@H](C2C=CC=CC2)Oc2cc(O)cc(O)c21</smiles>

2

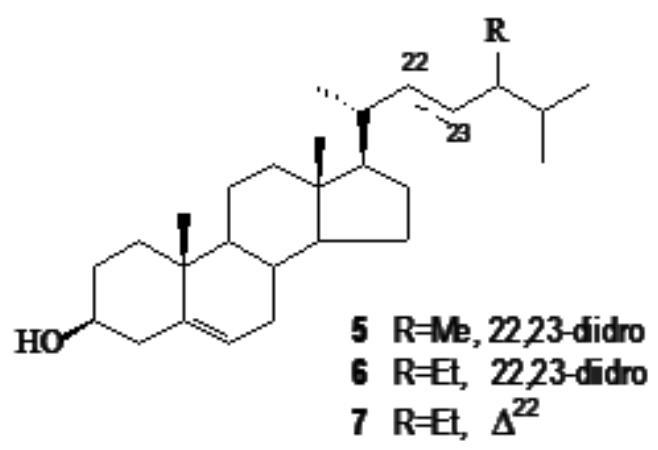

Figure 1. Compounds isolated from Swartzia apetala Raddi var. glabra. 
Table 1. Extract and compounds activity of Swartzia apetala Raddi var. glabra toward Candida spp. measured by agar diffusion method.

\begin{tabular}{l|ccccccc}
\hline \multirow{2}{*}{ Yeast strains } & \multicolumn{6}{c}{ Extract and compounds tested/diameters of inhibition zones (mm) } \\
\cline { 2 - 8 } & extract & stilbene & flavanone & pterocarpan & lupeol & steroids & Positive control \\
\hline C. albicans & 0 & $15 \pm 0,05$ & $14 \pm 0,05$ & $10 \pm 0,07$ & 0 & 0 & $30 \pm 0,06$ \\
\hline C. tropicalis & $13 \pm 0,10$ & $12 \pm 0,18$ & $7 \pm 0,01$ & $10 \pm 0,03$ & 0 & 0 & $25 \pm 0,03$ \\
\hline C. spp. & 0 & $11 \pm 0,07$ & $9 \pm 0,09$ & $10 \pm 0,04$ & 0 & 0 & $28 \pm 0,07$ \\
\hline C. parapsilosis & 0 & $16 \pm 0,08$ & $15 \pm 0,06$ & $10 \pm 0,09$ & 0 & 0 & $33 \pm 1,3$ \\
\hline C. guillermondii & $18 \pm 0,04$ & $16 \pm 0,09$ & $10 \pm 0,07$ & $13 \pm 0,05$ & 0 & 0 & $40 \pm 1,6$ \\
\hline C. lusitaneae & $11 \pm 0,01$ & $11 \pm 0,05$ & $11 \pm 0,08$ & $11 \pm 0,04$ & 0 & 0 & $35 \pm 0,08$ \\
\hline C. glabrata & $13 \pm 0,10$ & $13 \pm 0,02$ & $5 \pm 0,05$ & 0 & 0 & 0 & $27 \pm 0,40$ \\
\hline C. krusei & $11 \pm 0,02$ & $11 \pm 0,08$ & $9 \pm 0,10$ & $9 \pm 0,01$ & 0 & 0 & $22 \pm 0,04$ \\
\hline C. inconspicua & $17 \pm 0,08$ & $14 \pm 0,04$ & $12 \pm 0,11$ & $10 \pm 0,06$ & 0 & 0 & $32 \pm 0,07$ \\
\hline
\end{tabular}

yeasts were suspended in sterile saline and read by photometry (Densimat, bioMérieux, France) adjusted to $\mathrm{n}^{0} 0.5 \mathrm{McF}$ arland scale $\left(10^{6} \mathrm{CFU} / \mathrm{mL}\right)$. Afterwards, $5.0 \mathrm{~mm}$ of diameter wells were perforated and filled with $50 \mu \mathrm{L}$ of the extract $(25 \mathrm{mg} / \mathrm{mL})$ and $50 \mu \mathrm{L}$ of the compounds isolated $(1.0 \mathrm{mg} / \mathrm{mL})$. The plates were incubated at $37^{\circ} \mathrm{C}$ for 36 hours. All tests were carried out in triplicates. Myconazole nitrate (Vodol ${ }^{\circledR}$ batch 606401, União Química, Brazil) $(50 \mu \mathrm{L} ; 1.0 \mathrm{mg} / \mathrm{mL})$ was used as positive control. Solvent control (absolute ethanol) was included in each experiment as negative control. The antifungal activity was measured as the diameter $(\mathrm{mm})$ of clear zone around wells containing all products tested. The yeast utilized were Candida albicans ATCC 36802, C. lusitaneae ATCC 34449, C. guillermondii ATCC 6260, C. glabrata ATCC 2001, C. inconspicua ATCC 16783, C. parapsilosis ATCC 22019, C. krusei ATCC 34135, C. tropicalis ATCC 13803 and C. spp. 34147.

\section{RESULTS AND DISCUSSION}

The identification of the compounds 1-7 involved comparison of the spectral data, obtained through GC/MS, 1D and 2D NMR analysis, with values described in the literature for 5-hydroxy3-methoxystilbene 1, (Ngo \& Brown, 1998), 5,7-dihydroxyflavanone 2, (Markham \& Chari, 1976), 3-hydroxy-8,9- methylenedioxypterocarpan 3, (Bedir et al., 1999), lupeol 4, (Campos et al., 1991; Zanon et al., 2008) and a mixture of steroids campesterol $\mathbf{5}$, sitosterol 6 and stigmasterol 7 (Seo et al., 1988). Two of these compounds (1 and $\mathbf{2})$ are being reported by first time in the Swartzia genus (Figure 1).

The screening of the antifungal activity in vitro of the hexanic extract of the stem of $S$. apetala and the compounds isolated against nine yeast of the Candida genus are show in the Table 1. Compared with the positive control results, the activity of the extract may be due to the synergic effect of the three active compounds together. From the results obtained with the three compounds the compounds $\mathbf{1}$ and $\mathbf{2}$ showed activity against most of yeast analyzed with inhibition zone values of $((15 \pm 0.05 \mathrm{~mm})$ C. albicans, $(16 \pm 0.08 \mathrm{~mm})$ C. parapsilosis and $(16 \pm 0.09 \mathrm{~mm})$ C. guillermondii for the compound $\mathbf{1}$. Activity of the compound $\mathbf{2}$ towards C. albicans $(14 \pm 0.05 \mathrm{~mm})$ and C. parapsilosis $(15 \pm$ $0.06 \mathrm{~mm}$ ) were similar to compound $\mathbf{1}$. Amongst the three compounds tested, the compound $\mathbf{3}$ was the less active showing as most significant result against $C$. guillermondii $(13 \pm 0.05 \mathrm{~mm})$ and no inhibition against C. glabrata. The other compounds showed no inhibition halo.

\section{ACKNOWLEDGMENTS}

The authors thank Universidade Estadual do Norte Fluminense (UENF), Fundação de Amparo à Pesquisa do Estado do Rio de Janeiro (FAPERJ), Coordenação e Aperfeiçoamento de Pessoal de Ensino Superior (CAPES) and Conselho Nacional de Desenvolvimento Científico e Tecnológico (CNPq) for fellowships and financial support.

\section{REFERENCES}

Aguiar JS, Costa MCCD, Nascimento SC, Sena KXFR 2008. Atividade antimicrobiana de Lippia alba (Mill.) N. E. Brown (Verbenaceae). Rev Bras Farmacogn 18: 436440.

Bedir E, Çalis I, Aquino R, Piacente S, Pizza C 1999. Trojanoside H: a cycloartane-type glycoside from the aerial parts of Astragalus trojanus. Phytochemistry 51: 1017-1020.

Braz-Filho R, Moraes MPL, Gottlieb OR 1980. Pterocarpans from Swartzia laevicarpa. Phytochemistry 19: 20032005.

Campos AM, Oliveira FS, Machado MIL, Braz-Filho R, Mattos FJA 1991. Tritrerpenes from Cedrela odorata. Phytochemistry 30: 1225-1226.

Formiga MD, Gottlieb OR, Midori K, Almeida EL, Pereira MOS, Magalhães MT 1974. Constituents of Brazilian Leguminosae. Phytochemistry 14: 828.

Hadaceck F, Greger H 2000. Testing of antifungical natural products: methodologies, comparability of results and assay choice. Phytochem Anal 11: 137-147.

Jadhav VJ, Pal M, Mishra GS 2003. Etiological significance of Candida albicans in otitis extern Mycopathologia 156: 313-5.

Magalhães AF, Tozzi AMGA, Santos CC, Serrano DG, Zanotti- 
Magalhães EM, Magalhães EG, Magalhães LA 2003. Saponins from Swartzia langsdorffi: Biological activities. Mem Inst Oswaldo Cruz 98: 713-718.

Markham KR, Chari VM 1976. Carbon-13 NMR Spectroscopy of Flavonoids. Chapman and Hill, London, 1976, p.113.

Ngo K, Brown GD 1998. Stilbenes, monoterpenes, diarylheptanoids, labdanes and chalcones from Alpinia katsumadai. Phytochemistry 47: 1117-1123.

Rangel-Frausto MS, Wiblin T, Blumberg HM, Saiman L, Patterson J, Rinaldi M, Pfaller M, Edwards JEJr, Jarvis W, Dawson J, Wenzel RP 1999. National epidemiology of mycoses survey (NEMIS): Variations in rates of bloodstream infections due to Candida Species in seven surgical intensive care units and six neonatal intensive care units. Clin Infect Dis 29: 253258.

Rizzini CT, Mors WB 1995. Botânica Econômica Brasileira. Ambito Cultural, Rio de Janeiro, p. 136.

Rojas R, Bustamante B, Ventosilla P, Fernández I, Caviedes L, Gilman RH, Lock O, Hammond GB 2006. Larvicidal, antimicobacterial and antifungal compounds from the bark of the Peruvian plant Swartzia polyphylla DC. Chem Pharm Bull 54: 278-279.

Sanchez CS, Rocha AFI, Pinheiro MLB, Andrade CHS, Monte FJQ 1999. Brachyrachisina: isoflavona inédita de Swartzia (Leguminosae). Acta Amazônica 29: 419422.

Seo S, Uomori A, Yoshimura Y, Takeda K, Seto H, Ebizuka Y, Noguhi H, Sankava V 1988. Biosyntheses of sitosterol, cycloartenol, an 24-methylenecycloartenol in tissue cultures of higher and of ergesterol in yeast from $\left[1,2-{ }^{13} \mathrm{CH}_{2}\right]$ and $\left[2-{ }^{13} \mathrm{CH}_{3}\right]$ acetate and $\left[5-{ }^{13} \mathrm{CH}_{2}\right]$. $J$ Chem Soc Perkin Trans I: 2407-2412.

Zanon RB, Pereira DF, Boschetti TK, Santos M, Athayde ML 2008. Fitoconstituintes isolados da fração em diclorometano das folhas de Vernonia tweediana Baker. Rev Bras Farmacogn 18: 226-229. 